The BMJ

kabbasi@bmj.com Follow Kamran on Twitter@KamranAbbasi Cite this as: BMJ 2021;375:n2497 http://dx.doi.org/10.1136/bmj.n2497 Published: 14 October 2021

\title{
Covid-19: Fatal errors, not fatalism, created UK's public health disaster
}

\section{Kamran Abbasi executive editor}

Was it fatalism that allowed 138 ooo covid deaths in the UK? Were these deaths bound or decreed to have happened? The answer is, simply, no. Did fatalism kill people in social care, or differentially target people who are disadvantaged? Were ethnic minorities victims of "covid fatalism"-and is it "career fatalism" that means that they are less likely to be shortlisted and appointed to medical jobs, as a new investigation reveals (doi:10.1136/bmj.n2460; doi:10.1136/bmj.n2451)? ${ }^{12}$

Was it fatalism that denied frontline health and social care professionals adequate personal protective equipment during the pandemic-and even now still exposes them to risks of airborne transmission and accusations of fakery (doi:10.1136/bmj.n2473)? ${ }^{3}$ The answers remain no. Fatalism, we're told, ignored pandemic lessons of history and lessons from other countries. Fatalism failed to implement adequate contact tracing and border controls.

Fatalism sidelined local public health teams and institutions, pumped billions into private hospitals and private contractors (doi:10.1136/bmj.n2471), ${ }^{4}$ and then disbanded Public Health England in the middle of a pandemic, creating a new body that has regrettably replaced "inequalities" with "disparities" (doi:10.1136/bmj.n2323). ${ }^{5}$ Fatalism, the villain of the piece, ignored advice from behavioural science experts and promoted a narrative of behavioural fatigue (doi:10.1136/bmj.m2982). ${ }^{6}$

Fatalism is the awkward conclusion of the joint inquiry by the House of Commons Health and Social Care Committee and the Science and Technology Committee into the UK's pandemic response (doi:10.1136/bmj.n2487; doi:10.1136/bmj.n2485; https://blogs.bmj.com/bmj/2021/10/12/chris-hamdithering-and-delays-hampered-the-uks-covid-19response). ${ }^{7-9}$ The verdict is damning, but the wording is a weasel explanation for the UK's calamitous pandemic failures. Negligence, incompetence, and dereliction of duty are closer to the mark. Indeed, the report skips over the government's misuse of billions of pounds of public funds to enrich associates.

Perhaps anything harsher was too much to expect from a committee chaired by a former health secretary who oversaw a number of pandemic preparation exercises without implementing their recommendations. Exercise Alice, for one, identified the very areas where the government has failed (doi:10.1136/bmj.n2485; doi:10.1136/bmj.n2475). ${ }^{810}$ Little wonder, then, that the existence of this exercise was concealed. If Jeremy Hunt knew nothing of this, as he mystifyingly claims, what of the medical officers, science advisers, NHS managers, and government officials involved in that exercise who sat on their hands and sealed their lips as the UK's death toll mounted?
The many premature deaths in the UK are put into sharp perspective by the low death toll and economic robustness of New Zealand (doi:10.1136/bmj.n2476), ${ }^{11}$ South Korea, and China, for example. The UK's story is one of extreme dysfunction within government and its scientific advisory committees and of complacent disregard for life and suffering. The story is one of political victory at all costs and an absolute disdain for accountability and personal and collective responsibility. Even now, government ministers are trivialising these grave errors as wisdom in hindsight, while their leader is holidaying and partying like it's 1999.

Yes, the UK succeeded in procuring vaccines and evaluating drugs for covid-19 (doi:10.1136/bmj.m3379), ${ }^{12}$ but those worthy successes of science and procurement should not be used as cover for the gross ineptitude that failed hundreds of thousands of people and their families. The human and economic disaster of covid-19 should not be shrugged off as scientific and political fatalism. The stark errors are not apparent because of hindsight; the government was challenged at each step and often forewarned of the damaging consequences of its decisions.

The alarm bells about the UK's inadequate response were being rung loudly by March 2020

(doi:10.1136/bmj.m1284). ${ }^{13}$ A few weeks later this had already become too little, too late, too flawed (doi:10.1136/bmj.m1932). ${ }^{14}$ When the state's scientists belatedly changed tack, the government dithered. Even today the UK is willing to accept 750 deaths a week as the new normality and is an outlier in policies of children's vaccination and school safety and ventilation. In our dystopian present, Jürgen Klopp, a football manager, speaks with greater public health wisdom than some scientists and politicians (doi:10.1136/bmj.n2472). ${ }^{15}$

Fatalism is a distraction and a disingenuous explanation for "one of the UK's worst ever public health failures." Leadership may have no magic formula (doi:10.1136/bmj.n2465), ${ }^{16}$ but what we need is for elected representatives and their advisers to accept responsibility, and it is this disregard for accountability that has proved fatal and prolongs the ordeal for the bereaved families (https://www.theguardian.com/politics/2021/oct/12/covid-responseone-of-uks-worst-ever-public-health-failures). ${ }^{17}$

Linton S. White doctors in London are six times more likely to be offered jobs than black doctors. BMJ2021;375:n2460

Linton S. Black and Asian doctors still face discrimination when applying for jobs in the NHS. BM/2021;375:n2451.

3 Oliver D. David Oliver: When doctors are accused of faking covid experiences. BMJ 2021;375: $\mathrm{n} 2473$.

Limb M. Covid-19: Private hospitals "fell well short" in delivering care during the pandemic, says report. BMJ2021;375:n2471 doi: 10.1136/bmi.n2471 pmid: 34625407 
5 Scally G. England's new Office for Health Improvement and Disparities. BMJ2021;374:n2323. doi: 10.1136/bmj.n2323 pmid: 34561222

6 Michie S, West R. Behavioural, environmental, social, and systems interventions against covid-19. BMJ2020;370:m2982. doi: 10.1136/bmj.m2982 pmid: 32723732

7 O'Dowd A. Covid-19: Government's handling of pandemic had "big mistakes," MPs say. BMJ 2021;375:n2487doi: 10.1136/bmj.n2487.

8 McKee M. The UK government tested the response to a coronavirus-why are we only discovering this now?BMJ 2021;375:n2485.

$9 \quad$ Ham C. Dithering and delays hampered the UK's covid-19 response. BMJ Opinion. Oct 2021. https://blogs.bmj.com/bmj/2021/10/12/chris-ham-dithering-and-delays-hampered-the-uks-covid19-response.

10 lacobucci G. UK was advised to stockpile PPE and screen travellers in 2016 after coronavirus modelling. BMJ2021;375:n2475. doi: 10.1136/bmj.n2475 pmid: 34635492

11 Dyer O. Covid-19: Is New Zealand's switch in policy a step forward or a retreat?BMJ 2021;375:n2476. doi: 10.1136/bmj.n2476 pmid: 34635487

12 Rochwerg B, Agarwal A, Siemieniuk RA, etal. A living WHO guideline on drugs for covid-19. BMJ 2020;370:m3379. doi: 10.1136/bmj.m3379 pmid: 32887691

13 Pollock AM, Roderick P, Cheng KK, Pankhania B. Covid-19: why is the UK government ignoring WHO's advice?BM/2020;368:m1284. doi: 10.1136/bmj.m1284 pmid: 32229543

14 Scally G, Jacobson B, Abbasi K. The UK's public health response to covid-19. BMJ 2020;369:m1932. doi: 10.1136/bmj.m1932 pmid: 32414712

15 lacobucci G. Sixty seconds on ... sportspeople and jabs. BMJ2021;375:n2472. doi: 10.1136/bmj.n2472 pmid: 34625463

16 Gerada C. Clare Gerada: Leadership has no magic formula. BMJ 2021;375:n2465doi: 10.1136/bmj.n2465.

17 Sample I, Walker P. Covid response "one of UK's worst ever public health failures." Guardian. Oct 2021. https://www.theguardian.com/politics/2021/oct/12/covid-response-one-of-uks-worstever-public-health-failures.

This article is made freely available for use in accordance with BMJ's website terms and conditions for the duration of the covid-19 pandemic or until otherwise determined by BMJ. You may use, download and print the article for any lawful, non-commercial purpose (including text and data mining) provided that all copyright notices and trade marks are retained. 